\title{
From the Trap of Difference to That of Excellence: The Women Artists, Their Works and the Artistic Field
}

\author{
Lourdes Méndez \\ Anthropology of Art, Faculty of Fine Arts, Universidad del País Vasco/University of the Basque Country, \\ Bilbao, Spain \\ Email: lourdes.mendez@ehu.es
}

Received November $15^{\text {th }}$, 2013; revised December $17^{\text {th }}, 2013$; accepted January $25^{\text {th }}, 2014$

\begin{abstract}
Copyright (C) 2014 Lourdes Méndez. This is an open access article distributed under the Creative Commons Attribution License, which permits unrestricted use, distribution, and reproduction in any medium, provided the original work is properly cited. In accordance of the Creative Commons Attribution License all Copyrights (C) 2014 are reserved for SCIRP and the owner of the intellectual property Lourdes Méndez. All Copyright @ 2014 are guarded by law and by SCIRP as a guardian.
\end{abstract}

\begin{abstract}
The works produced both by ethnic artists and by women artists lead us to suspect that either the aesthetic sensibility of art experts has not evolved sufficiently or that it is not "pure" enough to free them from the load of prejudices surrounding such works and those who produce them. To illustrate this problem, we will first offer two substantially different examples. The first concerns Report No. 8 commissioned by Emakunde, the Basque Women's Institute (Spain) and published in the mid-nineteen nineties. The second refers to the Kunstkompass, a tool used to establish the ranking of the one hundred most internationally recognised artists. Next, we will examine the four clearly ranked circles of recognition existing in the artistic field. Finally, to demonstrate up to what point the position of women artists in the artistic field is that of inside yet out, we will analyse the content of two articles published in mid-February 2008 in the Babelia supplement of the El País spanish newspaper about two exhibitions of works by women artists.

Keywords: Artistic Field; Charismatic Ideology; Artistic Recognition; Sociosexual Ideology; Women and Ethnic Artists
\end{abstract}

\section{Introduction}

The dominant sociosexual ideology about the meaning of being a man or a woman used to interpret the roles and functions each sex should accept as pertaining to a hypothetically male or female nature, together with the persistence in the art world of a charismatic ideology that denies any influence of the social marker called sex in gaining artistic recognition, places female artists in a position I qualify as being inside yet outside the artistic field. Women are materially within the field in terms of creative output and as producers of works that are exhibited and sold in various circuits, but when the time comes for them and for their works to achieve a significant degree of recognition, the fruit of their professional careers, most of them disappear. To analyse this process, one must keep in mind that in spite of what is affirmed with increasing emphasis, the evaluation of artists and works by art experts, a fundamental step for obtaining legitimacy in an extraordinarily competitive, tricky market, is filtered by a longstanding sociosexual order that has created a differential "valence" between the sexes and their hierarchy (Héritier, 1996). To forget this would be equivalent to accepting the idea that art is a universal language that can be deciphered through pure aesthetic sensibility. The works produced both by ethnic artists and by women artists lead us to suspect that either the aesthetic sensibility of art experts has not evolved sufficiently or that it is not "pure" enough to free them from the load of prejudices surrounding such works and those who produce them.
To illustrate this problem, we will first offer two substantially different examples. The first concerns Report No. 8 commissioned by Emakunde, the Basque Women's Institute (Spain) and published in the mid-nineteen nineties. The second refers to the Kunstkompass, a tool used to establish the ranking of the one hundred most internationally recognised artists. Next, we will examine the four clearly ranked circles of recognition existing in the artistic field. Finally, to demonstrate up to what point the position of women artists in the artistic field is that of inside yet out, we will analyse the content of two articles published in mid-February 2008 in the Babelia supplement of the El País Spanish newspaper about two exhibitions of works by women artists.

\section{Report No. 8 and the Kunstkompass}

The analysis of Emakunde's Report No. 8 on Las mujeres en la producción artística de Euskadi (Women in the Artistic Production of Euskadi) is of double interest because it provides quantitative data and turns to art experts to interpret them. The data are from 1991 and examine the prizes awarded to women artists, particularly the Gure Artea, the participation of female artists in galleries in the Basque Country, the access of these artists to the working world and their participation in the International Contemporary Art Fair (ARCO) in 1991. The report also takes into account that the number of female students enrolled in the Fine Art School of the University of the Basque Country who finished their studies was significantly higher 
than that of male students. The figures compiled show that women artists are underrepresented in all areas that would enable them to consolidate their position within the contemporary art context. The report states that $30 \%$ of female artists exhibited their work in the Basque Autonomous Community during 1991 compared with $70 \%$ of male artists and that in ARCO ' 91 the presence of works by women artists was about $5 \%$ without there being any significant differences between the data referring to Spain and that regarding Germany, Italy, France, Great Britain and the United States. The figures are clear: the unequal presence in significant contemporary art contexts of female and male artists is an empirically verifiable fact. If one knows that for a work to be labelled contemporary it is not enough to have been created by a live artist since this is "an international label that constitutes one of the greatest, constantly reevaluated measurements of artistic competitiveness” (Moulin, 1992: p. 45), this can be interpreted as the material consequence of an unequal evaluation by art experts of works produced by male and female artists. Here we must insist that for a work to be labelled contemporary, its creator, whether male or female, should be part of the international circuits and become well known through presence in galleries, exhibitions, museums and showrooms. The artist must also make gallery directors, dealers, curators, collectors and critics contribute to the promotion, evaluation and acquisition of his/her works. A male critic and art historian and a female gallery director, both from the Basque Country, were in charge of interpreting the data from Report No. 8 that showed an inequality between male and female artists in the Basque Country's artistic field.

Upon considering why the number of female artists showing their work in Basque galleries is lower than that of male artists, the art critic insists on a historically correct event: "women began to work in art later than men." He then reaches a curious conclusion, "currently multiple generations and graduation classes of artists coexist and therefore there are more male artists than female” (Report No. 8, 1994: p. 158). Apparently for this critic the initial situation of numerical inferiority of female artistsin the artistic field continues to persist, a kind of historical handicap affecting the present. He fails to take into account that more women than men graduate in Fine Art, a statistical fact that should have been reflected in this coexistence of several generations and graduation classes of artists by a greater presence of women, but let's continue. Switching directly from the world of figures to the business world and from the business world to sexual roles in a series of fascinating cause-effect relationships, the critic declares that, "since those purchasing (art) are men, they buy work by men [...] even though they also purchase the artist's projection in terms of potential earning power. In this aspect, it seems that men are better able to continue their work and career, whereas women have their tasks, their children [...]. This financial and psychological reasoning exists” (Report No. 8, 1994: p. 158). From a similar standpoint, upon being questioned about the participation of women artists in commercial circuits, the female gallery director replies [...] sex has nothing to do with it; what is important is the work [since] the only thing that interests people is the work of art. It may be true that more women give up. The art world in itself is very difficult, not because one is a man or a woman. There are more men than women in everything that stands out (Report No. 8, 1994: p. 167).

And returning to the critic, when speaking of ARCO he declares that this matter is very different, because other interests have an influence here. A gallery is accepted according to economic interests and presents artists according to that. It is not the same; it has nothing to do with representation, juries or anything, only money (Report No. 8, 1994: p. 167). While it is true that commercial interests are behind events such as ARCO and there is no jury to choose male or female artists, it is also true that each gallery works with some artists and not with others. More specifically, each gallery has a group of artists and works that it wants to promote, and if it decides to take to ARCO works by one of its male artists rather than those by one of its female artists, this decision is in line with the gallery director's criteria, be he/she male or female. If we accept what the art critic says, these criteria seem to be as subjected to the market as those used by ARCO when deciding which galleries will be awarded a stand in the Fair.

In short, what the two art experts interpreting the data in Report No. 8 find is that 1) there are more male artists than female artists; 2) men buy the works and therefore they buy work by men; 3) the important thing is the work of art, not the artist's; and 4) women have their tasks and children and this may affect their professional careers. What they do not say is why, if the important thing is the work of art and not the sex of the person producing it, men mainly buy works by other men, nor why the fact of being a woman can influence the professional career of female artists, whereas the fact of being a man also seems to have an effect, but the opposite one, because "there are more men than women in everything that stands out”. Since they do not say what is really of interest, in order to make it come out, we must recall how the artistic field works. According to Bourdieu's definition, it is: "a system of objective relationships between agents (artists, gallery directors, critics, dealers, exhibittion curators, art theoreticians...) or institutions (for example, museums, legitimate aesthetic tastes) and a battlefield for the monopoly on consecrating power, where the value of the works and the belief in this value are constantly created" (Bourdieu, 1977: p. 7).

Charismatic ideology, the keystone in this field, acts as a disseminator of the collective belief that neither the artists nor their works owe anything to anyone and that if only a few from each generation are recognised as great artists and their works accepted as true works of art, it is due to the fact that unselfish "cultural heirs", who possess an exquisite aesthetic taste and "cultural capital" have been able to discover them. This credo, renewed periodically, is what prevents questions about the social, sexual, economic, political and symbolic conditioning factors intervening in the artistic field. This credo also conceals two empirically verifiable facts: first, that "the arts are hierarchical and work due to the authority of certain forerunners who have set the standards, [whereas] imitators merely follow this authority” (Schwimmer, 1995: p. 16), and second, that in all activities our societies continue to entrust the "role of 'setting the standards' to the masculine sex" (Schwimmer, 1995: p. 17). If we keep these ideas in mind, the following will be better understood.

The Kunstkompass is a tool that has been used since 1970 as an indicator of the value of artists' reputations. Its objective is to prepare every year a list of the one hundred most recognised artists. To do this, users of this tool created in Germany by a journalist turn to a kind of informal jury comprising art critics, museum directors and large private collectors. The opinions of these experts, together with data taken from reviews on this or that artist published in the large international art magazines, 
statistics on the participation of male and female artists in important exhibitions that offer worldwide exposure such as the Documenta in Kassel or the Venice Biennale, and solo exhibitions in great museums and art centres, areall used to establish the artists' ranking. No Spanish artist was included in this list in 2001 and it was dominated by artists from the United States and Germany (Quemin, 2002). The representation of female artists did not exceed $10 \%$. While in 2001 the Kunstkompass examined 10,000 artists to make its classification, in 2007 its database contained over 150,000 artists, which, as one of its executives has pointed out, means it is impossible for art professionals to have an overview of all these careers, a perspective that according to this executive "a machine can offer". And this machine, conscientiously loaded with data, gave the same percentage in 2007 as in 2001 of female artists in the ranking's first one hundred positions. One can easily deduce from these statistics that those who actually control the artistic field are western males of American, German or British nationality. Due to this, it could be suggested that they are the ones who continue to reproduce the conceptual framework that makes it difficult to legitimise female and ethnic artists and, by extension, their works.

\section{The Artistic Field and the Four Circles of Recognition}

There are four clearly ranked circles of recognition in the artistic field (Bowness, 1989). Although they do not all act simultaneously, they provide feedback to one another. These four circles do not escape the dominant values of sex/gender in each society and historical period nor the ethnicity or class position of the artist in question. The first circle, comprising male and female artists, is the most restricted. Just as in the other three circles, judgments are made here on works that, despite claims to the contrary, are not due exclusively to purely intra-aesthetic or artistic issues. This circle is of great importance for both male and female artists, since it is where their peers recognise not only them but also their works. The second circle is composed of dealers and collectors who, in contact with the artists, carry out financial transactions concerning their works. The third is made up of various art experts - critics and exhibition and museum curators-who are often linked to public institutions and who are separated both in time and space from male and female artists. The fourth circle is formed by a heterogeneous receiving audience that through galleries, exhibitions and museums has access to the works and sometimes to the artists producing them. This receiving audience, however, is not a legitimising force, because legitimisation has already taken place in the first three circles. What is offered to this audience has already been recognised as a work of art by various experts. The Bowness analytical model pays a lot of attention to how artistic reputations are built in time and space during the modern era, a construction that is particularly important for western artists and also for artists formerly described as "primitive" who are now considered ethnic (Méndez, 2009).

If there is something in the twentieth-century artistic field that characterises both the male and female artists comprising the first circle of recognition, it is their desire to distance themselves from the dominant definitions of art. In so doing, they create works that cannot emerge as such (be they by male or female artists) if the perception and appreciation criteria in force are applied to them (Michaud, 1999). As the art of the first avant-garde movements demanded in its day, artistic recognition of these works and artists requires that these criteria be overcome and replaced by others. Until this happens, the practical effect of the continuance of the previous perception and appreciation criteria is an initial rejection of these works and artists by this heterogeneous audience that in any case lacks legitimacy to issue aesthetic judgments or artistic standards. The initial rejection of new works and artists therefore would be "an eventuality [...] that is part of the work itself [...] [since] the artist's work rests on transgression of the cognitive boundaries that define what can or cannot be perceived as art" (Heinich, 1998: p. 78). In turn, critics, curators, dealers and collectors play a role opposite that of the artists and "their task consists in integrating within the artistic field what has been conceived to transgress boundaries and to extend the borders of the artistic environment to include objects or acts that traditionally were not relevant” (Heinich, 1998: p. 79). This task of integration still seems to be problematic for female artists and their works.

If we add to what has been said up to now the very widespread ultraliberal concept of individual success as well as some of the commonplaces developed by postmodern discourse, the panorama of social and symbolic conditioning factors that female artists must face is a difficult one. Difficult because the impact of these commonplaces on contemporary art has contributed to the emergence of a politically correct subject matter in this art, that of sexual difference, which must be examined while also considering the interactions between the current redefinition of art, the identity of the male or female artists and their works and the possibility that these works (even if explained) communicate something to a public that often does not know the keys to contemporary art and refuses to relinquish the identifying certainty of sex/gender. In this respect, the problem is both artistic and political, since what is debated in contemporary art is "not so much a consensus on a definition of what is beautiful and what is artistic talent, as a consensus on the definition of art and the artist's identity” (Heinich, 1998: p. 74). One of the most powerful commonplaces of the postmodern approach is the idea according to which today's individual "moves constantly and furtively within the scenario of public life in order to manifest him/herself in his/her multiple and not always clear realities and at the same time showwhat he/she considers the most appropriate, the latest, the ethos, eidos and pathos compared to a structuring and compulsive logos” (Azcona, 1996: p. 40).

This commonplace, which concerns the way the individual is understood, is integrated with others such as sexual difference, lack of authenticity, hybridisation and racial blending that are all very successful in contemporary art. In terms of the identity of subjects, the American anthropologist Clifford has probably expressed such commonplaces with greatest clarity. He believes that collective identity must be conceived as a discontinuous process of invention that is often hybrid. Therefore, he states that when intervening in an interconnected world, one always "lacks authenticity" to various degrees: trapped between some cultures and involved in others (Clifford, 1995 [1988]: pp. 25-26). If this is applied to visual works and artists, the main idea would be to defend that works and artists, wherever they come from, are hybrid products (and subjects). But this notion of hybridisation conceals the specificity of certain cultures, works and artists, and leaves intact the implicit factors of sexual order, a longterm symbolic order that founded the differential 
"valence" of sexes and their hierarchy. According to the female anthropologist Héritier (1996), no society is free of this differential valence of the sexes, which structures each of their social and symbolic worlds, ranks what is male and female, and attributes a higher value to what is male than to what is female. The hierarchy of this differential "valence" of the sexes would have to be transformed in order to have the sexual condition of the artist in question become irrelevant for those who have the power to create creators, "consecrate" their works, define legitimate aesthetic taste and produce authorised knowledge on art. Therefore, it is necessary to learn how this symbolic sexual order conditions the attribution to male artists and their works of the cultural and symbolic legitimacy continuously denied female artists and their works. We also have to know how this order affects a system of "consecration" that was not built outside of the order but is based on it.

Given this situation, it is time to propose some issues that feminist research on the artistic field should explore without losing sight of the intersections between the local and global contexts in which the works of current women artists are produced and circulate. If, as I believe, plastic and visual creation does add something to the position held by female artists and their works in contemporary art, this something is residual. Research must continue on why most art experts continue to evaluate the works of female artists from the viewpoint of a sexual difference that only seems to affect women. Other issues include whether "the dominant major and secondary circuits of museums, galleries and publications (those wecould call 'universalisers') build the 'international artistic scene'” (Mosquera, 2001: p. 23). Furthermore, if as has already been pointed out, the Anglo-Saxon countries, particularly the United States, play a key role in the market "in the formulation of artistic options and specifically the consecration of leading artists" (Quemin, 2002: p. 9), the impact this global context has on the degree of recognition afforded female artists must be clarified.

\section{Two Articles, Two Exhibitions}

At the midpoint of the 2008 edition of ARCO, the El País newspaper (February 16th, 2008) published on facing pages in its Babelia supplement, two articles that in my opinion merit fairly detailed comment. The first, signed by Ángela Molina, focused on the exhibition The Furious Gaze, curated by Xabier Arakistain and Maura Reilly. The second, signed by historian and art critic Francisco Calvo Serraller, dealt with another exhibition, Amazonas del arte nuevo (Amazons of New Art), curated by Josep Casamartina and Pablo Jiménez. We shall begin with the latter.

Commenting the merits of this exhibition, which gathered together 116 works by 41 female artists who had participated in the successive "isms" of the twentieth century, Calvo Serraller, a skilful avoider of the feminist movement's political and social role, attributes a decisive role in "women's liberation” to World War I. According to Calvo Serraller, who only places quotation marks around liberation and not women's, that war enabled women to reliably learn about "their capacity to do, enjoy and endure anything”. Overlooking the feminist struggles and demands of the era, and after enumerating a long list of the women artists selected for the exhibition, he writes: “I don't believe that it is a bad calling card for an exhibition presented in terms of gender demands the fact that, thanks to good exploratory work, it enlarges our always limited baggage of knowledge; however [...] its contribution is much more ambitious and fertile, because the selection of works is frankly splendid and so after seeing them, I wouldn't say visitors overlook 'gender' but they do come to forget it".

Two things catch our attention if this paragraph is read closely: the subtlety with which this art critic who publishes his articles week after week in El País minimises the fact that the exhibition's curators designed it in terms of a “'gender' claim”, and instead highlights their "good exploratory work" and how, having done this, he concludes that thanks to this good work in the selection of the pieces, the artists' "gender" is forgotten without being overlooked. Speaking clearly, what he is saying to us once again is that what is important is the quality of the works and not the sex of the artist producing them. And once again he fails to respond to the following: 1) why the excellence of these artists and works has not been recognised until now; 2) why sex is overlooked without; and 3) why did we have to wait until 2008 for this "good exploratory work" to have been possible. Like many of his peers, the historian and art critic Calvo Serraller does not seem to know that over three decades ago, female historians and feminist art critics began to recover the history of women artists and to organise exhibitions like the one that in 1982, under the title L'Autre moitié de l'avantgarde, brought together some of these female artists that Calvo Serraller seems to have just discovered.

Signed by Ángela Molina, the second article is titled: "Las mamás de Blancanieves” (Snow White’s Mums), and is subtitled: "The Furious Gaze exhibition in Vitoria explores the false answers that feminism gives to art.” It is true that schools of information sciences usually insist on how important it is to create an eye-catching headline that holds the attention of newspaper readers. In this case, the objective is fulfilled completely and, to ensure no one misses it, I anticipate some clues as to the article's content, attributing real subjects to the title and subtitle: the "mums" are the feminists; the Snow Whites are the female artists; and the poisoned apple comprises the "false answers that feminism gives art”. Other attributions may also fit - that is the good and the bad thing about such metaphoric titles and subtitles. From a supposedly critical position, the author of the article writes that the model of art history "is of necessity overwhelmingly masculine. It describes the evolution of forms as a crucial war between fathers and sons and defines the creative process from the metaphorical viewpoint of a sensual (if not sexual) encounter between the painter and his muse, [...] and this seems to continue today when creation labelled as pertaining to women has ended up becoming a fetish for multinational museums”.

Instead of explaining why the art history model is masculine by necessity, why it persists and why "creation labelled as pertaining to women has ended up becoming a fetish for multinational museums," Molina continues her article by alluding to some exhibitions by female artists held in 2007 that, in her opinion, served to "illustrate the historical dispossession and degradation of the feminine principle and to analyse a culture whose definitions of creative authority are covertly patriarchal.” After such initial remarks in which she mixes a bit of everything, Molina focuses on The Furious Gaze exhibition whose "great merit rests in its (healthy) capacity to 'offend' the viewer given the context in which it is held: Vitoria, a deeply conservative city. [...] and indirectly shows that feminism, as has been the case with other social movements, has been displaced by the current new social policies.” 
What Molina is telling us is that since feminism is behind The Furious Gaze and since it is a thing of the past, only viewers from conservative Vitoria, who are apparently unaware of these "current new social policies" (what social policies is she referring to?-perhaps the neo-liberal policies we experience daily?) may feel "offended" by the works on display. And so she comes to her evaluation of these works. As seen, in contrast to Calvo Serraller, Molina does not avoid feminism-given the exhibition she is describing that would have been impossibleshe simply decides that it is a thing of the past and that what we have now is a mythology of feminism that "is born the moment it falls behind [...] [That] should serve to demand of the work an aesthetic dignity allied with its own capacity to overcome certain historical conditioning factors.”

The work's aesthetic dignity? Its capacity to overcome historical conditioning factors? We are immersed in a philosophical perspective belonging to the formalist aesthetic, and hidden behind it is the sacrosanct idea of the artwork's autonomy. After a brief review of the works of some artists, Molina concludes that "unalterably feminine, these women artists with a 'furious gaze' dance in order to escape the mirror of male authority but not enough to overcome their eagerness to play in the same representation context. Once playing within this context, they have to wait in line in front of the same window. And if not, they must spit out the poisoned apple, step out of the glass coffin and dance another dance. A dance of authority".

Whoever recalls the story of Snow White knows that it was not her mum but her stepmother, obsessed with her own physical appearance and beauty, who interrogated the mirror, asking it repeatedly "Mirror, mirror on the wall. Who is the fairest of us all?" until the mirror replied Snow White and triggered off the well-known drama. Apparently for Molina it is egalitarian feminism that has placed women artists before the mirror of masculine authority and not masculine authority that has imposed this on women in each and every field of social activity, including art, as a filter to evaluate their practices. And it is even worse because women artists have accepted this game and that they must be subject to the same rules. Are they not already subjected to the same rules, like it or not, whether or not they agree with them? And are these rules the same for both sexes? Given the criteria of value and aesthetic judgment that numerous experts continue to apply to female artists and their works, everything seems to indicate that they are not. Or does the article's author mean that the works of some female artists with a "furious gaze" do not reach the level of "excellence" required -by whom? - to obtain a significant degree of recognition in the contemporary art field. Finally, spitting out the poisoned apple, if our interpretation is correct, would mean rejecting the mythology of egalitarian feminism and asserting themselves as "unalterably feminine" in order to dance the dance of authority from within this unalterable femininity. Is Molina referring to "the dance of difference? To obtaining authority in art by affirming the difference of what is feminine?"

In case this is true, we shall conclude with a reminder that in 1979 the French feminist materialist sociologist, Colette Guillaumin, wondered why at certain times "some oppressed groups [...] claim their 'difference'” (Guillaumin, 1992: p. 89). She affirmed that the word "difference" has been taken over by "all of our 'specific' characteristics [...] to be united with the traditional and folkloristic ideologies that from blackness to femininity have always intended that those dominated have some- thing specific and that everything in them be particular. (Undoubtedly, the others, those who dominate, are satisfied with being general)” (Guillaumin, 1992: p. 91). Furthermore, this author insisted that to emphasise the difference and claim that as women they have their own nature implies believing that "groups of men and women can exist in themselves and offer a permanence that enables them to define themselves outside the relationship. This is an imaginary way of affirming the independence of the dominated group” (Guillaumin, 1992: p. 93). When speaking of men and women, one is speaking of two social groups that maintain a certain relationship formed through specific practices. Practices that affect the life "of all the individuals concerned and govern their existence [...] no aggression has as its objective to take from us [...] tenderness, dreams or the detergent that cleans softly. [...] everything flows together to guarantee us those privileges and the material means to cultivate these exquisite features [...]. We will not be deprived of children, the elderly, family relationships, preparing meals or listening to men's personal, professional, political and amorous perplexities. We will not be freed of what also makes possible the 'black traces' of difference: the hysteria, mythomania, fury, fatigue, desperation and madness. [...] So let's not get upset about an imaginary fear, it will not take away what makes us different. Let's not lose our time asking for what we already have” (Guillaumin, 1992: p. 103).

Actually, the difference was already given to women just as they were given an unalterable "feminine" attribute and in the artistic field, that designation has not led to the recognition of female artists—nor of "ethnic artists" —as standard setters in art.

\section{REFERENCES}

Azcona, J. (1996). Teoría y práctica en antropología social. Bilbao: UPV/EHU.

Bourdieu, P. (1977). La production de la croyance: Contribution à une économie des biens symboliques. Actes de la Recherche en Sciences Sociales, 13, 13-45. http://dx.doi.org/10.3406/arss.1977.3493

Bowness, A. (1989). The conditions of success. How the modern artist rises to fame. London: Thames \& Hudson.

Chadwick, W. (1992). Mujer, arte y sociedad. Barcelona: Destino.

Clifford, J. (1995). Dilemas de la cultura. Barcelona: Gedisa.

Guillaumin, C. (1992). "Question de différence” in guillauMin, C. Sexe, race et pratique du pouvoir. L'idée de nature (pp. 83-106). Paris: Côté-femmes.

Heinich, N. (1996). Être artiste. Les transformations du statut des peintres et des sculpteurs. Paris: Klincksieck.

Heinich, N. (1998). Des conflits autour de l'art contemporain. Le Débat, 98, 72-86. http://dx.doi.org/10.3917/deba.098.0072

Héritier, F. (1996). Masculino/femenino. El pensamiento de la diferencia. Barcelona: Ariel.

Méndez, L. (2009). Antropología del campo artístico. Del arte primitivo [...] al contemporáneo. Madrid: Síntesis (currently being printed).

Michaud, Y. (1999). Critères esthétiques et jugement de goût. Nîmes: J. Chambon.

Mosquera, G. (2001). Algunas notas sobre globalización y curadoría internacional. Revista de Occidente, 238, 17-30.

Moulin, R. (1992). L'Artiste, l'institution et le marché. Paris: Flammarion.

Quemin, A. (2002). L'art contemporain international: Entre les institutions et le marché (Le rapport disparu). Paris: J. Chambon/ Artprice.

Schwimmer, E. (1995). El signo y su lectura. In L. Méndez (Ed.), Antropología de la producción artística. Madrid: Síntesis. 